\title{
A NEW AFROTROPICAL SPECIES OF ORMYRUS WESTWOOD, 1832 (HYMENOPTERA, CHALCIDOIDEA, ORMYRIDAE)
}

\author{
J. L. Nieves-Aldrey, M. Hernández Nieves \& J. F. Gómez
}

\begin{abstract}
A new species, Ormyrus fernandinus sp. n. (Hymenoptera, Chalcidoidea, Ormyridae), is described from the island of Bioko (Equatorial Guinea). Collected with Malaise trap, the biology of the new species is unknown. The differential morphological features of the new species with respect to known afrotropical Ormyrus species, and its phylogenetic relationships are discussed.
\end{abstract}

Key words: Ormyrus, new species, Equatorial Guinea, Bioko.

\section{RESUMEN}

Una nueva especie afrotropical de Ormyrus Westwood, 1832

(Hymenoptera, Chalcidoidea, Ormyridae)

Se describe una nueva especie, Ormyrus fernandinus sp. n. (Hymenoptera, Chalcidoidea, Ormyridae), de la isla de Bioko (Guinea Ecuatorial). La especie fue colectada con trampa Malaise por lo que se desconoce su biología. Se discuten los caracteres distintivos fundamentales de la nueva especie en relación a las especies de Ormyrus conocidas en la region Afrotropical, y sus relaciones filogenéticas.

Palabras clave: Ormyrus, especie nueva, Guinea Ecuatorial, Bioko.

\section{Introduction}

The Ormyridae is one of the smallest families of Chalcidoidea with about 125 described species (Noyes, 2002). Ormyrids are small chalcidoids easily recognized by their metallic coloration, enlarged metacoxa, not exserted ovipositor and characteristic crenulated and foveolate sculpture of the metasoma. The family is divided into three genera: Eubeckerella Narendran, 1999 and Ormyrulus
Bouček, 1986, both monotypic from Asia, and Ormyrus Westwood, 1832, a genus with an almost cosmopolitan distribution that includes all other species of the family. Doğanlar (1991) splits Ormyrus into a number of genera, but his opinion has not been followed by subsequent authors (Hanson, 1992; Askew, 1994). The Ormyridae are mainly parasitoids of gall-inducing insects, especially Hymenoptera: (Cynipidae, Agaonidae, Eurytomidae and Pteromalidae), and Diptera (Tephritidae and

* Departamento de Biodiversidad y Biología Evolutiva. Museo Nacional de Ciencias Naturales (CSIC). C/ José Gutiérrez Abascal, 2. 28006. Madrid, España. E-mail: aldrey@mncn.csic.es, jgomez@mncn.csic.es. 
Cecidomyiidae). Some species have been recorded also as parasitoid of gall-inducing Coleoptera and Thysanoptera (Narendran, 1999; Noyes, 2002; Yao \& Yang, 2004).

Eleven species have been described from the Afrotropical Region; one species $O$. langlandi Girault, is widely distributed worldwide; three species were described from Madagascar, three from Zimbabwe, and one each from Senegal, Chad, Malawi and South Africa (Bouček et al., 1981; Noyes, 2002). From Equatorial Guinea there were no previous published records of Ormyridae.

During an insect carried out in Novembre 2003 in Equatorial Guinea we sorted a series of unidentified specimens of Ormyridae from the Malaise trap samples collected on the island of Bioko (formerly known as Fernando Poo when the country was a colony of Spain). These individuals represent a new species of Ormyrus that is described in this paper.

\section{Material and methods}

The material was collected originally in $70 \%$ ethanol. From the type series one adult female and one male of $O$. fernandinus sp. nov., were dissected, air dried, mounted on a stub and coated with gold, and micrographs were taken with a FEI QUANTA 200 scanning electron microscope (high vacuum technique) for several standardized views. Forewings were mounted in Euparal on slides, and examined under a stereomicroscope. Images of adult habitus were taken with a digital camera attached to a Leica stereomicroscope. Terminology for morphological structures and abbreviations follows Gibson (1997).

\section{Ormyrus fernandinus Nieves-Aldrey, Hernández \& Gómez sp. nov.}

(figs 1-3; habitus female, fig. 3B)

TYPE MATERIAL. Holotype. 1 \& , card mounted, EQUATORIAL GUINEA, Bioko island, Batoicopo, 3³8'452'N 8 38'449"E, $201 \mathrm{~m}$; collected with Malaise trap, 20-22/XII/2003 (J. L. Nieves-Aldrey \& J. F. Gómez leg). Deposited in Museo Nacional de Ciencias Naturales (Madrid) (MNCN) (catalog no. 9693). Paratypes. $2 \sigma^{\top} \sigma^{7}, 5$ 우 우. Same locality and data as the holotype. Deposited in MNCN; one paratype female deposited in South African Museum (Iziko Museums of Cape Town).

AdDitional MATERIAL. One female and one male dissected for SEM observation.

DESCRIPTION.

Female. Body length 2.3-2.8 mm. Body metallic green with golden reflections on parts of coxae and propodeum; metasomal tergites 4-7 dark violet basally and green apically, syntergum dark violet. Other parts of body differ in colouration as follows: antenna fuscous, except scape, which is light brown, legs light brown except coxae and metafemora which are the same colour as body. Wings smoky brown or slightly darkened; venation dark brown.

Head. In dorsal view as wide as mesoscutum, and slightly wider than metasoma; $2.1 \mathrm{x}$ as broad as long (Fig. 1C); temples about one-sixth length of an eye; POL 1.8 x OOL, posterior ocellus separated from orbit by about $1.4 \mathrm{x}$ its diameter. Head in anterior view (Fig. 1A) $1.18 \mathrm{x}$ as broad as high; upper face as broad as height of an eye; malar space about $0.3 \mathrm{x}$ the height of an eye and $0.5 \mathrm{x}$ the oral space; malar sulcus extended ventrally to the mouth fossa; genae narrow in frontal view. Ventral margin of clypeus slightly sinuate and slightly projected over the mandibles. Toruli situated slightly above level of lower orbit, their ventral margin separated from level of lower orbit by about one torulu's diameter, and separated from posterior margin of clypeus by about $2.5 \mathrm{x}$ the diameter of a torulus; distance separating toruli from anterior ocellus about $1.1 \mathrm{x}$ as long as distance separating toruli from posterior margin of clypeus; distance separating toruli from inner margin of a compound eye $1.3 \mathrm{x}$ the diameter of a torulus; separation between toruli about $0.6 \mathrm{x}$ the diameter of a torulus; scrobes deeply impressed, converging upwards and extended dorsally near ventral margin of median ocellus, scrobal depression extended ventrally to a distance $1.4 \mathrm{x}$ the diameter of a torulus. Sculpture of face, excepting scrobal area, costulate; supraclypeal area with weak costulate sculpture. Head in posterior view (Fig. 1B) more or less triangular, occipital carina present, not extended ventrally below the foramen magnum; situated closer to occipital foramen than to vertex. Distance between occipital and oral foramina about $1.2 \mathrm{x}$ the height of occipital foramen; median strip of gula hairy; occiput with costulate sculpture.

Mouthparts (Figs. 1A, 1B). Mandibles large, both with two teeth, one apical acute tooth and another broad blunt basal tooth. Maxillary stipes more or less triangular. Maxillary palp five-segmented; fifth segment long, longer than fourth, with an apical seta as long as segment. Labial palp three-segmented.

Female antenna (Fig. 1E). Flagellum with 11 connate articles; length of pedicel plus flagellum slightly longer than width of head; scape $4 \mathrm{x}$ as long 



Fig. 1.- Ormyrus fernandinus n. sp. (SEM). A) head anterior view. B) head posterior view. C) head dorsal view. D) female antenna, scape and first segments. E) female antenna. F) male antenna, scape and first segments.

Fig. 1.- Ormyrus fernandinus n. sp., (SEM). A) vista anterior de la cabeza. B) vista posterior de la cabeza. C) vista dorsal de la cabeza. D) antena de la hembra, escapo y primeros segmentos. E) antena de la hembra. F) antena del macho, escapo y primeros segmentos. 

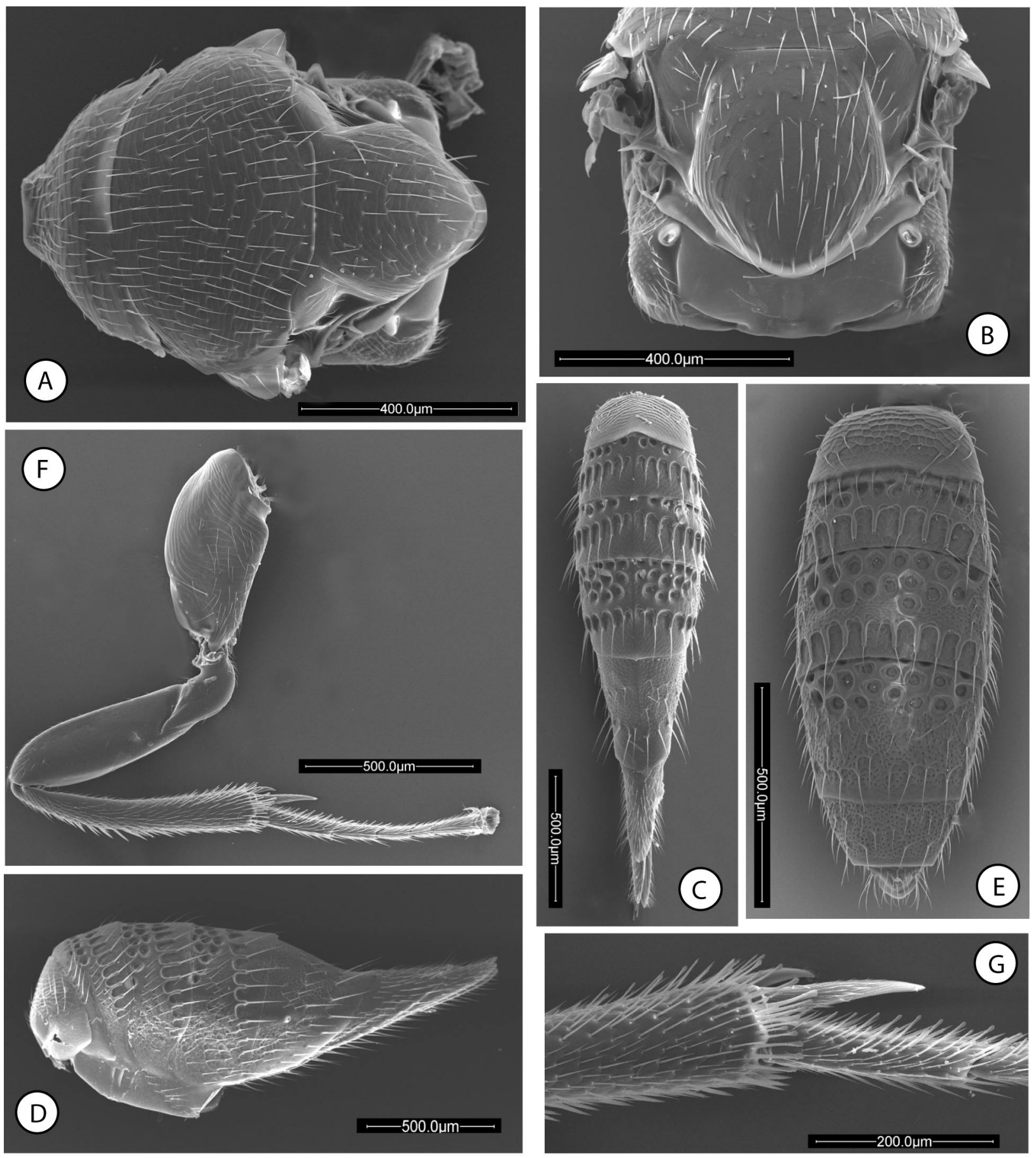

Fig. 2.- Ormyrus fernandinus n. sp., (SEM). A) mesosoma dorsal view. B) scutellum and propodeum posterior view. C) metasoma of female dorsal view. D) metasoma of female lateral view. E) metasoma of male dorsal view. F) posterior leg. G) metatibial spur.

Fig. 2.- Ormyrus fernandinus n. sp., (SEM). A) vista dorsal del mesosoma. B) vista posterior de escutelo y propodeo. C) vista dorsal del metasoma de la hembra. D) vista lateral del metasoma de la hembra. E) vista dorsal del metasoma del macho. F) pata posterior. G) espina metatibial. 
as wide; two anelli visible, first anellus small lamellate, second anellus twice as long as first anellus, and 2.6 times as wide as long (Fig. 1D); flagellum filiform, not broadened apically; first funicular segment slightly longer than pedicel, $1.1 \mathrm{x}$ as long as wide; Funicular segments 2 to 4 as long as first funicular segment; clava with length $1.1 \mathrm{x}$ combined length of Funicles 5 and 6; elongate placoideal sensilla present in one row (6-7) on all flagellar segments excepting anelli, and on first funicular segment arranged in two rows (Fig. 1D); tips of sensillae in the apical rows extended slightly beyond the apical margins of segments.

Mesosoma. In dorsal view (Fig. 2A) $1.4 \mathrm{x}$ as long as broad; in lateral view strongly convex dorsally (Fig. 3A), $1.3 \mathrm{x}$ as long as high; pronotum and mesoscutum with long setae; pronotum in dorsal view more or less bell shaped with an anterior narrower part or neck, and a posterior broader part with lateral margins strongly converging anteriorly; mesonotum with weak transverse strigate sculpture; notauli absent; scutellum almost as broad as long, about as long as mesoscutum in lateral view of mesosoma with postero-dorsal margin of scutellum projecting over the propodeum; frenal area of scutellum indistinct; prepectus much smaller than tegulae; pleural suture well marked; mesepimeron without visible sculpture; posterior margin of mesepimeron straight; postero-dorsal area of mesepimerum with three long setae; dorsellum medially hidden by the scutellum; propodeum medially about $0.3 \mathrm{x}$ as long as wide, without visible sculpture (Fig. 2B); medial and lateral carinae absent; propodeal spiracle large, prominent, oval, its anterior margin contiguous with posterior margin of metanotum; paraspiracular sulcus deep; callus with long setae.

Legs. Protibia $0.8 \mathrm{x}$ as long as protarsus; mesotibial spur $0.7 \mathrm{x}$ as long as mesotarsus; metacoxa enlarged (Fig. 2F), as long as metafemur and $1.6 \mathrm{x}$ as wide as metafemur; postero-dorsal margin of metacoxa slightly incised, medially with a sharp keel extended to posterior half of metacoxa; metacoxa with strigate sculpture on entire ventral and dorsal surfaces; metatrochanter in ventral view triangular, $1.5 \mathrm{x}$ as long as breadth of metafemur; metatibia with two spurs (Fig. 2G), the longer spur $0.8 \mathrm{x}$ as long as metatarsus; basitarsus $0.6 \mathrm{x}$ as long as combined length of subsequent tarsomeres. Tarsal claws simple, with a single tooth, the basal claw area with long erect setae and prolonged laterally into a triangular acute lobe.
Forewing (Fig. 3C). Length $0.7 \mathrm{x}$ as long as body; relatively long and narrow, about $2.8 \mathrm{x}$ as long as wide; relative lengths of veins submarginal: marginal: postmarginal: stigmal as 9:9:2:1; submarginal vein with a row of 8-10 long bristles; marginal vein with long setae, shorter towards postmarginal vein; costal cell with a row of setae; basal cell with two rows of setae, speculum rather setose, cubital setal line complete with an uninterrupted row of setae closing basal cell and speculum; basal setal line complete; speculum small, narrow, longer than wide; uncus short; marginal setae relatively long.

Metasoma (Figs 2C, 2D). Lanceolate, acuminate, slightly compressed, $1.8 \mathrm{x}$ as long as combined length of head and mesosoma and about $4 \mathrm{x}$ as long as wide in dorsal view; Mt2 with strigate sculpture, slightly shorter than Mt4; Mt3 short, concealed under Mt2; Mt4 about as long as Mt5 and $0.6 \mathrm{x}$ as long as Mt6, MT7 slightly longer than Mt6; Dorsal metasomal tergites, from Mt4, with a medial excision, appearing to have a medial double keel (Fig. 2C); Mt4 to Mt6 with transverse rows of strong crenulated sculpture; ridges of crenulated sculpture prolonged apically by long erect setae; $\mathrm{Mt} 4$ and Mt5 with a belt of deep foveae; Mt6 with three belts of deep foveolate sculpture; Mt7 with strong punctate sculpture, and two rows of weak crenulated sculpture; apical part of Mt7 and epipygium slightly angled upwards with respect to the rest of metasoma (Fig. 2D), epipygium about $2 \mathrm{x}$ as long as wide; cercus with 4-5 setae not longer than the other setae of Mt8; ovipositor sheath slightly exserted, 0.5 as long as epipygium.

Male (Figs 1F, 2E). Body length $1.5 \mathrm{~mm}$. Similar to female excepting as follows: antenna with all placoideal sensilla on flagellar segments disposed in one row; scape (Fig. 1F) with a ridge delimiting ventro-apical area, bearing 9-10 pores and a modified flat seta; metasoma (Fig. 2E) oval elongated and depressed dorsoventrally, $2.5 \mathrm{x}$ as long as wide, without dorso-medial carinae; Mt1 with strong reticulate sculpture; Mt5 and Mt6 with 3-4 rows of deep foveae; apical margin of Mt7 truncate.

Etymology. Named after Fernando Poo, the former name of Bioko island (Equatorial Guinea).

Biology. Unknown. The related species $O$. flavipes is associated with fig galls and Ficus species were present near the collection site. However, since different biologies have been reported for the 

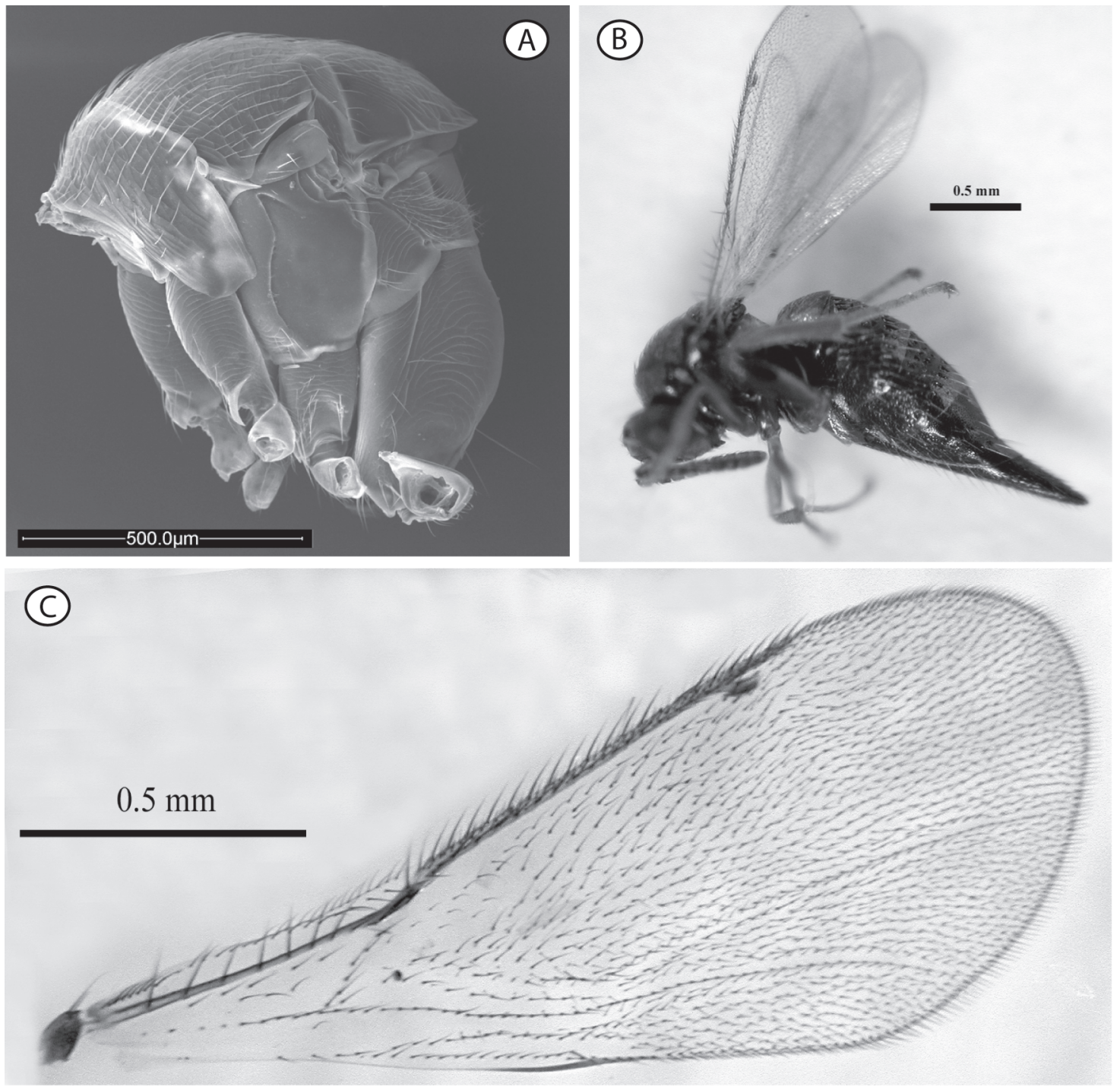

Fig. 3.- Ormyrus fernandinus n. sp. A) mesosoma lateral view (SEM). B) female habitus (LM). C) forewing of female (LM).

Fig. 3.- Ormyrus fernandinus n. sp. A) vista lateral del mesosoma (SEM). B) habitus de la hembra (LM). C) ala anterior de la hembra (LM).

afrotropical Ormyrus species, it can not be assumed that the new species is associated with figs.

Discussion. Ormyrus fernandinus is similar in coloration and general appearance to O. flavipes Bouček, a species described from Zimbabwe, ex gall Ficus burkei (Bouček et al., 1981). Main shared morphological features are the form of the female metasoma, with elongated epipygium, and the smooth propodeum. However females of the two species differ as follows: sixth funicular segment of antenna 1.2 times as broad as long (1.5 x in O. flavipes); wings infumated or darkened (hyaline in O. flavipes); marginal vein of forewing relatively longer, about $4.5 \mathrm{x}$ as long as postmarginal, whereas it is only $3.5 \mathrm{x}$ as long in Oflavipes; tergites 3-5 of metasoma with 1-3 rows of exposed foveolae $(O$. flavipes has no exposed belts of foveolae). Males of 
$O$. fernandinus and $O$. flavipes differ mainly in the shape of metasoma, relatively longer and narrower in the new species $(2.5 \mathrm{x}$, about $2 \mathrm{x}$ in $O$. flavipes $)$ and also in the numbers of rows of exposed foveolae on metasomal tergites 5-6 (3 rows in O. fernandinus, 2 in O. flavipes).

Bouček et al. (1981) pointed out that another three afrotropical species, $O$. engeniae Risbec, 1955, O. ornatus (Risbec, 1951) and O. striatus Cameron, 1907 have, like O. fernandinus, a double carina on metasomal tergites in the females. Ormyrus eugeniae Risbec, recorded only from Madagascar, is easily separated from our new species by its much more elongated epipygium; in contrast, $O$. ornatus from Senegal, displays a very short epipygium and a round stigma on forewing and is thus also different from $O$. fernandinus. $O$. striatus, a species described from South Africa, according to the description in Cameron (1907), differs in many characters from the new species, especially in its colouration and transverse segments of the antennal funicle.

The remaining afrotropical Ormyrus species are listed below. All can be separated from O. fernandinus by several features as follows:

Ormyrus australis Risbec, 1957, from Madagascar, by the colouration of body and wings, relatively shorter marginal vein and relative lengths of antennal segments.

Ormyrus chevalieri (Risbec, 1955) from Chad by its short rounded metasoma.

Ormyrus harongae (Risbec, 1952) from Madagascar by its reddish colouration and broadened antennae towards apex.

Ormyrus langlandi Girault, $1920(=$ O. decaryi (Risbec, 1955), by the metasomal tergites without a medial keel.

Ormyrus sculptilis Crosby, 1909, a parasite of Asphondylia terminaliae Tavares galling branches of Flueggea obovata (L.) from Zumbo, differs by the notauli being faintly indicated, the antennal funicle broadening towards the antennal clava, the yellowish tarsi and hyaline wings.

Ormyrus subconicus Bouček, 1981, a species associated with fig wasps from Zimbabwe, by its very short epipygium.

Ormyrus watshami Bouček, 1981, from Zimbabwe, can be separated from the new species by the almost bare basal area of the forewing, including speculum, and the transverse funicular segments.

Phylogenetic Relationships. The new species was included in a phylogenetic analysis of 21 spe- cies of Ormyrus, mainly from Europe, but including also one neotropical and two afrotropical species (Hernández Nieves \& Nieves-Aldrey, unpublished). The study was supported by the analysis of 148 characters of external morphology based on SEM pictures, and 5 characters of biology. Besides the unresolved basal phylogenetic relationships, the two analysis performed, Maximum parsimony and Bayesian Inference, showed $O$. fernandinus to be closely related to the european species O. monegricus Askew. This species, described from an arid area of Spain, is associated with galls of Cecidomyiidae on Salsola vermiculata (Askew, 1994). Under Bayesian Inference, the new species falls into a large clade including all the species of Ormyrus associated with oak galls, and also one undescribed afrotropical Ormyrus species associated with Rhoophilus galls from South Africa, $O$. cupreus Askew associated with a eurytomid wasp galling Ephedra, and the widely distributed $O$. orientalis Walker, 1871 a parasitoid of tephritid flies (Diptera) inducing galls in flower heads of Asteraceae.

\section{ACKNOWLEDGEMENTS}

We are grateful to Dr. Jorge Alvar, ex director of CNMTROP ISCIII and Jorge Cano, coordinator of the Proyecto de Salud Pública del Instituto Carlos III and their team of enthusiastic Ecuatoguinean entomologists, for their logistic support and help with field work during our stay in Equatorial Guinea. We thank Dick Askew and Simon Van Noort for critically reviewing the manuscript. We are grateful also to Laura Tormo for technical assistance in preparing the SEM photographs. Financial support was provided by the AECI, project "Los fondos zoológicos y documentales de Guinea Ecuatorial conservados en el Museo Nacional de Ciencias Naturales. Documentación y difusión" to Isabel Izquierdo Moya, and the Spanish Ministry of Education and Science, research project CGL2005-01922/BOS to J. L. NievesAldrey.

\section{References}

AsKew, R. R., 1994. Two new European species of Ormyrus (Hym. Ormyridae). Entomologist's Monthly Magazine, 130: 87-93.

BouČEK, Z., 1986. Taxonomic study of Chalcidoid wasps (Hymenoptera) associated with gall midges (Diptera, Cecidomyiidae) on mango trees. Bulletin of Entomological Research, 76: 393-407.

BouČEK, Z., 1988. Australasian Chalcidoidea (Hymenoptera), a biosystematic revision of genera of fourteen families, with a reclassification of species. $\mathrm{CAB}$ International. Wallingford. $832 \mathrm{pp}$. 
BouČEK, Z., Watsham, A. \& WieBes, J. T., 1981. The fig wasp fauna of the receptacles of Ficus thonningii (Hymenoptera, Chalcidoidea). Tijdschrift Voor Entomologie, 124(5): 149-233.

Cameron, P., 1907. Description of species of parasitic Hymenoptera, chiefly in the collection of the South African Museum, Cape Town (Second paper). Annales of South African Museum, 5: 203-225.

Crosby, C. R., 1909. Chalcid.flies reared from galls from Zumbo, East Africa. Broteria (Serie Zoologica), 9: 77-90.

DoĞANLAR, M. 1991. Systematic positions of some taxa in Ormyridae and description of a new species in Ormyrus from Turkey and a new genus in the family (Hymenoptera, Chalcidoidea). Turkiye Entomoloji Deergisi, 15(1): 1-3.

Gibson, G. A. P., 1997. Morphology and Terminology. In: Gibson, G. A. P., Huber, J. T. and Woolley, J. B. (eds) Annotated Keys to the Genera of Nearctic Chalcidoidea (Hymenoptera). NRC research Press. Ottawa: 16-44.

Girault, A. A., 1920. Some insects never before seen by mankind. Privately published. Brisbane. 4 pp.

Hanson, P. 1992. The Nearctic species of Ormyrus Westwood (Hymenoptera: Chalcidoidea: Ormyridae). Journal of Natural History, 26:1333-1365.

NARENDRAN, T. C., 1999. Indo-Australian Ormyridae (Hymenoptera: Chalcidoidea). University of Calicut. Kerala. 227 pp.

Noyes, J. S., 2002. Interactive Catalog of World Chalcidoidea, $2^{\mathrm{a}}$ ed. The Natural History Museum and Dicky Yu. CD-ROM.

RisBEC, J., 1951. Les chalcidoides de l'A frique occidentale française. Mémoires de l'Institute Français de l'Afrique Noire, 13: 7-409.

Risbec, J., 1952. Contribution à l'ètude des Chalcidoidea de Madagascar. Mémoires de l'Institut Scientifique de Madagascar (E), 2: 1-448.
RisbeC, J., 1955a. Torymidae et Agaonidae de Madagascar (Hym., Chalcidoidea). Annales de la Société Entomologique de France, 124: 147-194

RisBec, J., 1955b. Chalcidoides et Proctotrupides Africaines. Bulletin de l'Institute Français de l'Afrique Noire (A), 17: 533-580.

Risbec, J., 1957. Hyménoptères Proctotrupidae et Chalcidoides. Mémoires de l'Institut Scientifique de Madagascar (E), 8: 355-358.

Westwood, J. O., 1832. Descriptions of several new British forms amongst the parasitic hymenopterous insects. Philosophical Magazine, 3(1): 127-129.

YAO, Y. Y. \& YANG, Z., 2004. A new species of Ormyridae (Hymenoptera: Chalcidoidea) parasitizing a gall-making weevil on twigs of the bunge hackberry tree in China. Entomologica Fennica, 15: 142-148.
Recibido, 12-III-2007 Aceptado, 12-IV-2007 Publicado, 27-VI-2007 